\title{
Correlation between operating parameters and removal efficiency for chemically enhanced primary treatment system of wastewater
}

\author{
Ghada A. Al Bazedi (iD and Mona A. Abdel-Fatah
}

\begin{abstract}
Background: "Chemically enhanced primary treatment" (CEPT) is an approach to wastewater treatment. It can be utilized as a specially designed step in "biological" secondary treatment processes. The aim of this study is to create an empirical model of separation efficiency for wastewater chemically enhanced primary treatment.

Methods: The empirical model is undertaken using the simulation of the data obtained from pilot plant experimental studies using different types of coagulant ( $\mathrm{FeCl}_{3}$, alum, lime, and Magna-floc155).

The empirical modeling techniques used multivariate regression model. Different values of $\mathrm{BOD}_{5}, \mathrm{COD}$, TSS, as well as separation efficiencies for COD and TSS were investigated in accordance to achieve final effluent results that would meet the Egyptian standards limit.

Results: Multiple regression analysis showed that removal efficiencies of COD and TSS can be predicted to be $\left(R^{2}=\right.$ 0.973 and 0.978 , respectively).

Conclusion: The present work provides an approach for using chemically enhanced primary treatment of wastewater. The obtained results showed that the empirical model can predict removal efficiencies with $R^{2}=0.973$, and 0.978 for COD and TSS. The advantage of this model is that it would allow better process control and treatment efficiency. The results show that chemically enhanced primary treatment method can be used as an efficient method in conventional municipal wastewater treatment plants to reduce the organic load of biological treatment and enhance nutrients removal.
\end{abstract}

Keywords: Activated sludge, Multiple regression analysis, Wastewater treatment plant, Chemically enhanced primary treatment

\section{Background}

"Chemically enhanced primary treatment" (CEPT) is an approach to wastewater treatment and considered an alternative to the conventional primary treatment. It can be utilized as a specially designed preliminary step in "biological" secondary treatment processes. CEPT encompasses coagulation and flocculation processes and achieves

\footnotetext{
* Correspondence: bazedi@yahoo.com

Chemical Engineering and Pilot Plant Department, National Research Centre, El-Bohouth Street, Dokki, P.O. Box 12622, Giza, Egypt
}

significant accretion increases in the deletion of pollutants from the influential stream (Ismail et al., 2012; Parker et al., 2000; Bisinella de Faria et al., 2015; Wang et al., 2009).

Efficiencies of removal rely upon mixing times, type of mixing (mechanical or hydraulic), and type of coagulant. Fresh alum " $\left(\mathrm{Al}_{2}\left(\mathrm{SO}_{4}\right)_{3} \cdot 18 \mathrm{H}_{2} \mathrm{O}\right)$ " is commonly used in wastewater treatment as a coagulant for "chemical precipitation" (Dong et al., 2019; Mian et al., 2018). The coagulant dose needed for a cure is based on wastewater nature, $\mathrm{pH}$ value, phosphate level, and injection factor (Tik \& Vanrolleghem, 2016; Abdel Fatah \& Al Bazedi, 2019).

\section{Springer Open}

() The Author(s). 2020 Open Access This article is licensed under a Creative Commons Attribution 4.0 International License, which permits use, sharing, adaptation, distribution and reproduction in any medium or format, as long as you give appropriate credit to the original author(s) and the source, provide a link to the Creative Commons licence, and indicate if changes were made. The images or other third party material in this article are included in the article's Creative Commons licence, unless indicated otherwise in a credit line to the material. If material is not included in the article's Creative Commons licence and your intended use is not permitted by statutory regulation or exceeds the permitted use, you will need to obtain permission directly from the copyright holder. To view a copy of this licence, visit http://creativecommons.org/licenses/by/4.0/. 
CEPT can be used to achieve many different goals in wastewater treatment facilities: (i) to increase the TSS elimination performance of the primary settling process based on substantial treatment, (ii) to limit organic loading rates thereby reducing the demand for oxygen in aerobic biological treatment facilities, (iii) to achieve excessive phosphorus removal through precipitation and ultimately to achieve excessive phosphorus removal through precipitation, and ultimately (iv) to allow increased hydraulic charging quotes to an existing PST, thereby enhancing plant life with excessive moist weather flows (Ayoub \& Abdel-fattah, 2016; Ayoub et al., 2017; Neupane et al., 2008).

During the CEPT process, larger flocs are assembled and these flocs are decumbent to faster settling. The treatment efficiency also increases with the increase of floc size significantly. Different studies showed that CEPT process has effectively removed $85 \%$ and $57 \%$ of total suspended solids (TSS) and biological oxygen demand (BOD), respectively. There were also significantly higher efficiencies in chemical oxygen demand (COD) and suspended solids (SS) removal such as $76 \%$ and 85\%, respectively (Svardal \& Kroiss, 2011; Kalogo \& Verstraete, 2000). Some researchers also investigated the impact of polymer addition in COD removal. There was a higher achieved efficiency in the removal of COD by adding a metal salt and anionic polymer in comparison with the addition of metal salt alone. In some studies, contradictory results indicate that adding polymer in each case does not contribute to performance (He et al., 2016; Irene, 2000; Guven et al., 2019). In the CEPT process, in addition to particulate COD, soluble COD may also be removed to some extent. It improves the transfer of COD from the liquid phase to the phase of sludge (Aiyuk et al., 2004).

Researchers have assessed and developed different models concerning CEPT (Parker et al., 2000) and assessed CEPT, while Ouali et al. (Ouali et al., 2009) have developed an empirical model between the physicochemical and biological parameters. Belhaj et al. (Belhaj et al., 2014) have studied the water parameters of sewage treatment plant after rehabilitation and explore them through descriptive and multivariable analysis. Arnell et al. (Arnell et al., 2016) developed a model for anaerobic co-digestion in Benchmark Simulation, while Arnell et al. (Arnell et al., 2017) created a multi-objective performance assessment for wastewater treatment plants by combining plant process models and life. Different researchers have assessed the use of coagulants and the effectiveness of combining chemical treatment with conventional processes. The current work investigates combining different coagulants together to reach acceptable removal efficiency to reduce the organic load of biological treatment and enhance nutrients removal.

\section{Methodology}

The main objective of the analysis was to investigate the relation between the operating parameters including COD, $\mathrm{pH}$, TSS, TDS, and the removal efficiency of both COD and TSS using enhanced primary treatment technology in Gitis and Hankins (Gitis \& Hankins, 2018). For the present work, samples were collected at the discharge from the grit removal chamber from the municipal wastewater treatment plant of Zenein, and of the effluent from the primary settling tank were collected; Table 1 below summarizes the wastewater's characteristics. Different types of coagulant $\left(\mathrm{FeCl}_{3}\right.$, alum, lime, and Magna-floc155), as well as different treatment capacities, were investigated. The effect of "pH" on the efficiency of the process has been assessed for each coagulant type, e.g., the removal percentage of "COD", turbidity, and "TSS". The effect of coagulant type and dosage, as well as $\mathrm{pH}$, was investigated. Investigated $\mathrm{pH}$ range is between 4 and 11.5.

1. Coagulants

(a) Alum $\mathrm{Al}_{2}\left(\mathrm{SO}_{4}\right)_{3}-16 \mathrm{H}_{2} \mathrm{O}$ with a purity of $97 \%$ and M.W.630.38 (ADWIC, El-Nasr Pharmaceutical Chemical Co.) investigated doses from 10 to $70 \mathrm{mg} / \mathrm{l}$

(b) $\mathrm{Fe}_{3}$ with a purity of $99 \%$ M.W.162.21 (RiedeldeHaen) investigated doses from 10 to $70 \mathrm{mg} / \mathrm{l}$

(c) Lime with a purity of 90\% M.W.74.09 (S.d FineChem Ltd Boisar) investigated doses from 200 to $500 \mathrm{mg} / \mathrm{l}$

2. Coagulant aids

(a) Magnafloc155, Magnafloc1011

A mathematical correlation was formulated using a multivariate regression model for experimental results between operating parameters and removal efficiency, and operating parameters and suspended solids level. The mathematical model is based on a list of experimental trials. According to the developed statistical analysis, we can detect the removal efficiency of an effective treatment design package. The validity of the developed model was conducted on the results of a list of experiments.

\section{Results \\ Experimental results}

According to the lab test results, it was readily noted that the $\mathrm{pH}$ optimal values are 6, 4, and 11.2 for alum,

Table 1 Analysis of municipal wastewater sample

\begin{tabular}{ll}
\hline Parameter & Grab samples \\
\hline COD, $\mathbf{m g} / \mathbf{l}$ & $430-800$ \\
Turbidity, FTU & $260-400$ \\
TSS, $\mathbf{m g} / \mathbf{l}$ & $377-825$ \\
$\mathbf{p H}$ & $7-8.2$ \\
Temperature, ${ }^{\circ} \mathbf{C}$ & $22-27$ \\
\hline
\end{tabular}


$\mathrm{FeCl}_{3}$, and lime, respectively. Experiments with alum show higher COD removals than those with $\mathrm{FeCl}_{3}$ and lime. A removal percentage as high as $85 \%$ was recorded for alum (at $\mathrm{pH}=6)$ when the dose was $50 \mathrm{mg} / \mathrm{lit}$. With $\mathrm{FeCl}_{3} 70 \%$ removals were reached at $\mathrm{pH}=4.7$ with lime, COD removals reached $62 \%$ on average. It should be noted, however, that all experiments do not have the same initial conditions.

Figure 1 depicts the removals obtained when using Alum at a dosage of $50 \mathrm{mg} / \mathrm{l}$, Alum + Magna-floc155 at dosages of 0.1 and 0.2, and Alum + Magna-floc 1011 at dosages of 0.1 and 0.2. Comparison of the results obtained indicates that the addition of $0.2 \mathrm{mg} / \mathrm{l} \mathrm{Magna-floc}$ 1011 improves the removal percentage about $2 \%$ only, overusing Alum alone.

Figure 2 shows the effect of adding coagulant aids to $\mathrm{FeCl}_{3}$ and using other coagulants (Alum/Lime) with it. It is observed from the figure that the addition of coagulant aids has no significant effect on removal percentages.

Figure 3 shows the addition of aid to lime, which shows it has no effect and using Lime alone is much better than using it in combination with any type of aid.

\section{Regression analysis}

The relation between TSS and operating parameters

The correlation between TSS and operating parameters (COD, pH, and TDS) using multiple regression analysis with coefficient of determination $R^{2}=0.997$. The relation is presented below.

$$
\begin{aligned}
\mathrm{SS}= & -312.25+(0.62203 \times \mathrm{COD}) \\
& +(30.03359 \times \mathrm{pH})+(0.127156 \times \mathrm{TDS})
\end{aligned}
$$

\section{Correlation between COD removal efficiency and operating parameters}

The correlation between TSS and operating parameters (COD, $\mathrm{pH}$, settling time, temperature, flow rate, TSS, and TDS) using multiple regression analysis with coefficient of determination $R^{2}=0.973$. The relation is presented below.

$$
\begin{aligned}
\% \text { COD removal } & =153.33+(-0.01574 \times \text { time }) \\
& +(-0.00338 \times \mathrm{Q})+(0.330142 \times \text { temp }) \\
& +(-4.74168 \times \mathrm{pH})+(0.02196 \times \mathrm{TDS}) \\
& +(-0.02651 \times \mathrm{SS})+(-0.02337 \times \mathrm{COD})
\end{aligned}
$$

\section{Correlation between SS removal efficiency and operating parameters}

The correlation between SS and operating parameters (COD, $\mathrm{pH}$, settling time, temperature, flow rate, SS, and TDS) using multiple regression analysis with Coefficient of determination $R^{2}=0.978$. The relation is shown below.

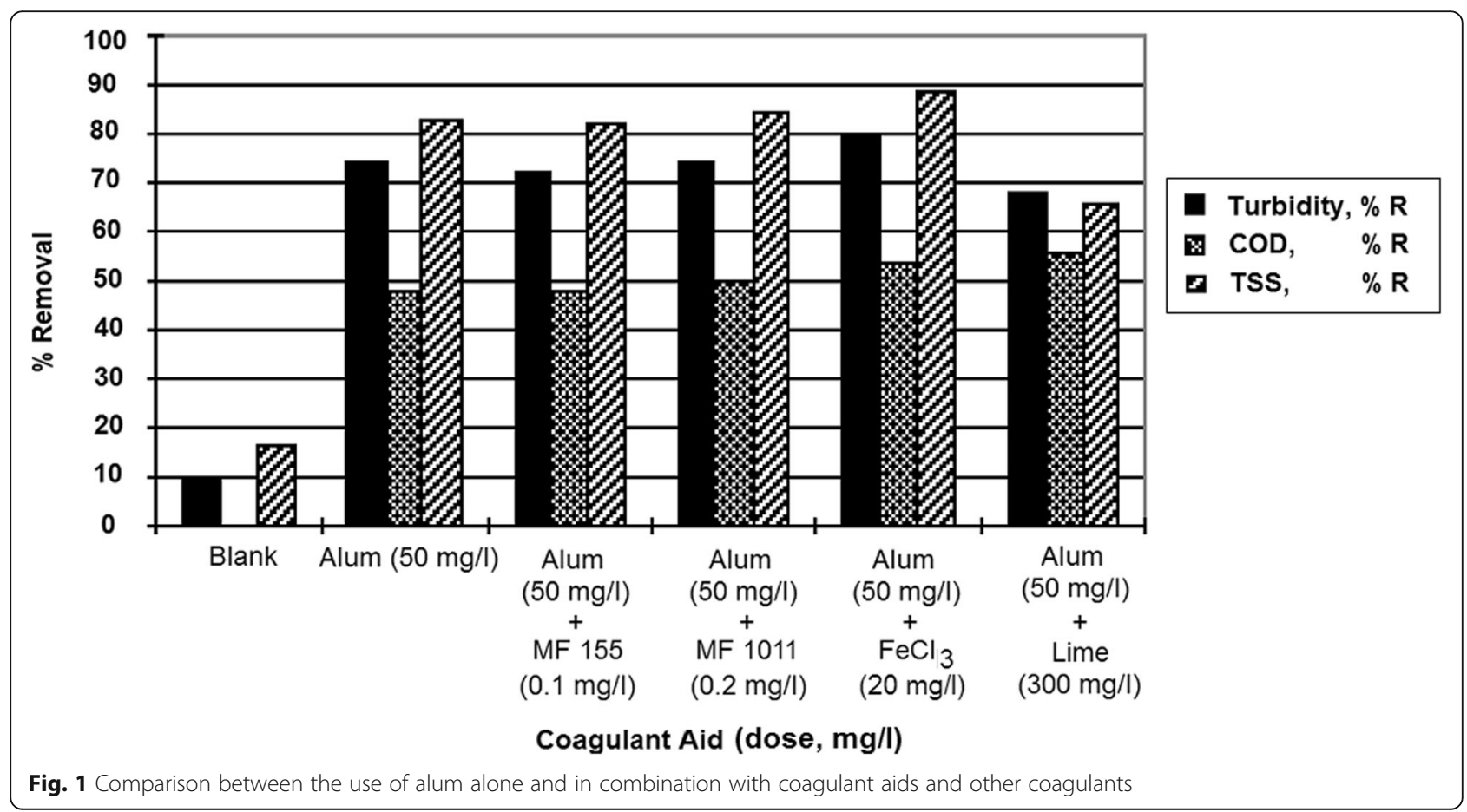



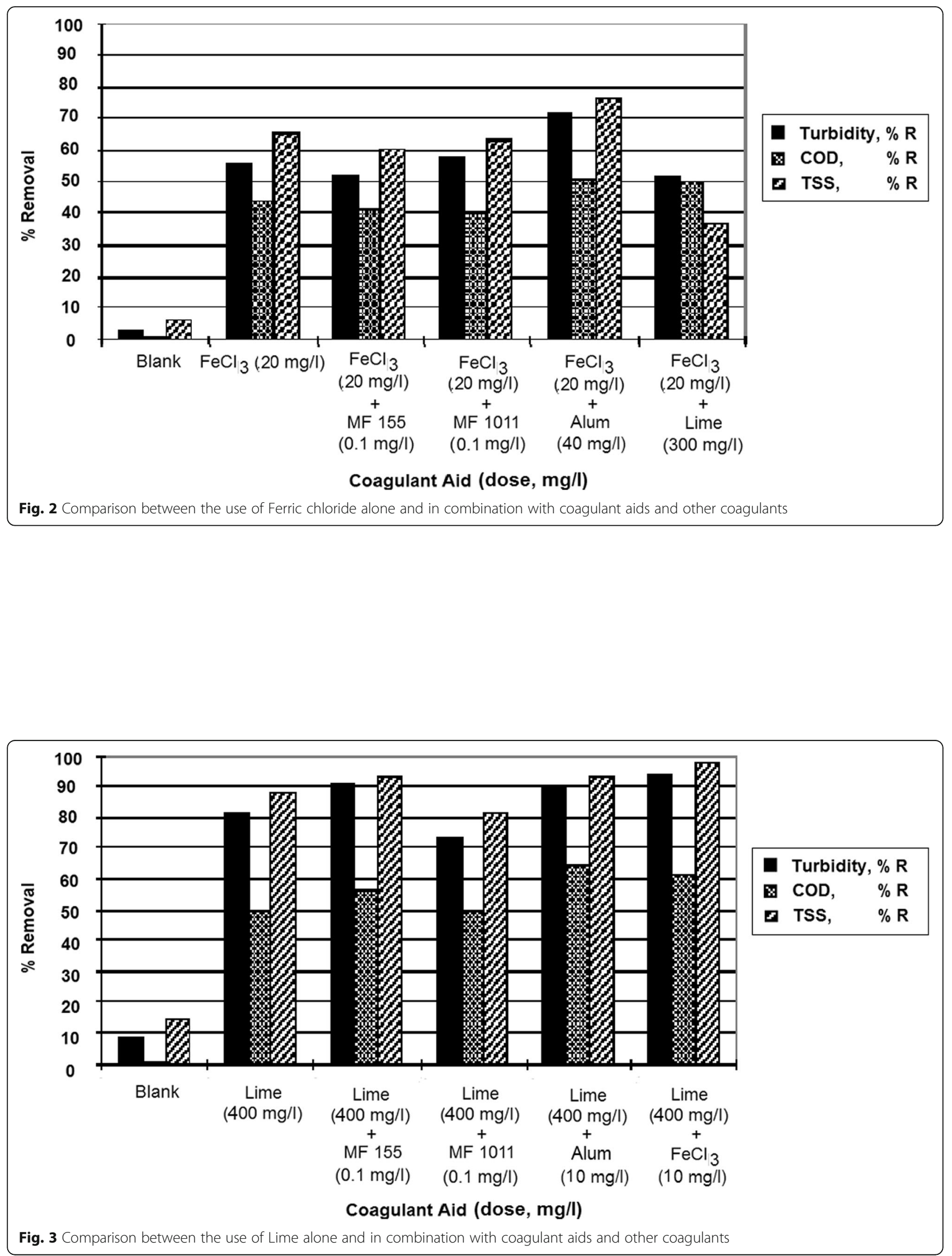


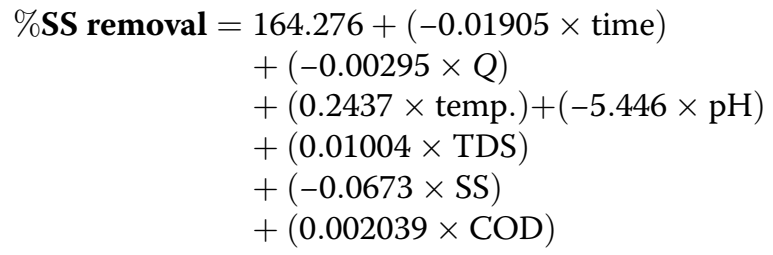

\section{Discussion}

Investigating the turbidity removal efficiency for various coagulant dosages indicates that $\mathrm{FeCl}_{3}$ and Alum are eminently effective coagulants for turbidity, with removal efficiency above $90 \%$. Lime shows to be less adequate and mediocre, where the removal efficiency reaches $80 \%$ when using a lime with a dose of $400 \mathrm{mg} / \mathrm{l}$. There is no appreciable effect of differing lime concentrations on turbidity removal efficiency. High removal efficiencies of $100 \%$ of total suspended solids were recorded with the use of Alum as a coagulant. High removals (>90\%) were also attained with $\mathrm{FeCl}_{3}$, while Lime gave a "TSS removal" of almost $80 \%$. The average removal ratio does not alter with an increase in the Lime dosage.

From the previous data, an Alum dosage of $50 \mathrm{mg} / \mathrm{l}$ is taken as the optimum dose. With $\mathrm{FeCl}_{3}$, it was noticed in dosages of $40 \mathrm{mg} / \mathrm{l}$ and higher, while for Lime, the optimum dosage was determined to be $400 \mathrm{mg} / \mathrm{l}$. The experiments revealed that it is better to use each coagulant alone due to interference between coagulant mixtures, which leads to undesired changes in $\mathrm{pH}$. Treatment with the use of Alum was proved to be more efficient than when using $\mathrm{FeCl}_{3}$ and lime, with the advantage that higher removal rates are attained at normal pH levels. Use of Alum has the additional advantage that there are fewer corrosion problems.

The regression analysis is used to predict the system's performance and its control level as the basis for further technique and control processes for Alum dosingenhanced primary treatment. Correlation matrix for the inlet parameters $\mathrm{pH}$, TSS, COD, and $\mathrm{BOD}_{5}$ of raw sewage entering the treatment plant is developed, in addition to \% TSS removal and \% COD removal.

The correlation matrix investigated the relationship between the selected variables. It was found that there is a strong relationship between the investigated variables and the pond recovery showed in the high coefficient of determination value. The results showed that the \% rejection of COD and SS was highly dependent on the variable flow rate, $\mathrm{pH}$, and TDS in the feed stream and independent of the TSS, COD, and settling time. The equation is valid for feed Alum dose of $50-80 \mathrm{mg} / \mathrm{l}$ and flow rate $10,000-16,000 \mathrm{~m}^{3} /$ day.

\section{Conclusion}

Multivariate regression model empirical model was developed using the simulation data obtained from the pilot plant and the experimental studies using different types of coagulant $\left(\mathrm{FeCl}_{3}\right.$, alum, lime, and Magna-floc 155). The removal efficiencies of COD and TSS can be predicted to be $\left(R^{2}=0.973\right.$ and 0.978 , respectively). The advantage of this model is that it would allow a better process control.

\section{Acknowledgements \\ Not applicable.}

Authors' contributions

All authors wrote, read, and approved the final manuscript.

Funding

Not applicable.

\section{Availability of data and materials}

The datasets used and/or analyzed during the current study are available from the corresponding author on reasonable request.

Ethics approval and consent to participate

Not applicable.

\section{Consent for publication}

Not applicable.

\section{Competing interests}

The authors declare that they have no competing interests.

Received: 29 May 2019 Accepted: 22 June 2020

Published online: 29 June 2020

\section{References}

Abdel Fatah, M. and Al Bazedi, G. 2019. Chemically enhanced primary. European Journal of Engineering Research and Science. 4, 4 (Apr. 2019), 115-123. doi: https://doi.org/10.24018/ejers.2019.4.4.1252.

Aiyuk S, Amoako J, Raskin L, Van Haandel A, Verstraete W (2004) Removal of carbon and nutrients from domestic wastewater using a low investment, integrated treatment concept. Water Research 38(13):3031-3042. https://doi. org/10.1016/j.watres.2004.04.040

Arnell M, Astals S, Åmand L, Batstone DJ, Jensen PD, Jeppsson U (2016) Modeling anaerobic co-digestion in Benchmark Simulation Model No. 2: parameter estimation, substrate characterization, and plant-wide integration. Water Research 98:138-146. https://doi.org/10.1016/j.watres.2016.03.070

Arnell M, Rahmberg M, Oliveira F, Jeppsson U (2017) Multi-objective performance assessment of wastewater treatment plants combining plant-wide process models and life cycle assessment. Journal of Water and Climate Change 8(4): 715-729. https://doi.org/10.2166/wcc.2017.179

Ayoub M, Abdel-fattah A (2016) A parametric study of alum recovery from water treatment sludge. Water Science and Technology 74(2):516-523. https://doi. org/10.2166/wst.2016.241

Ayoub M, Afify H, Abdel-fattah A (2017) Chemically enhanced primary treatment of sewage using the recovered alum from water treatment sludge in a model of hydraulic clariflocculator. Journal of Water Process Engineering, 19, 133-138. https://doi.org/10.1016/j.jwpe.2017.07.014

Belhaj D, Jaabiri I, Turki N, Azri C, Kallel M, Ayadi H (2014) Descriptive and multivariable analysis of the water parameters quality of Sfax sewage treatment plant after rehabilitation. IOSR Journal of Computer Engineering 16(1):81-91. https://doi.org/10.9790/0661-16178191

Bisinella de Faria A, Spérandio M, Ahmadi A, Tiruta-Barna L (2015) Evaluation of new alternatives in wastewater treatment plants based on dynamic modeling and life cycle assessment (DM-LCA). Water Research 84:99-111. https://doi.org/10.1016/j.watres.2015.06.048

Dong T, Shewa W, Murray K, Dagnew M (2019) Optimizing chemically enhanced primary treatment processes for simultaneous carbon redirection and phosphorus removal. Water 11(3):547. https://doi.org/10.3390/w11030547 
Gitis V, Hankins N (2018) Water treatment chemicals: trends and challenges. Journal of Water Process Engineering 25:34-38. https://doi.org/10.1016/j. jwpe.2018.06.003

Guven H, Dereli RK, Ozgun H, Ersahin ME, Ozturk I (2019) Towards sustainable and energy efficient municipal wastewater treatment by up-concentration of organics. Progress in Energy and Combustion Science 70:145-168. https:// doi.org/10.1016/j.pecs.2018.10.002

He Q, Wang H, Xu C, Zhang J, Zhang W, Zou Z, Yang K (2016) Feasibility and optimization of wastewater treatment by chemically enhanced primary treatment (CEPT): a case study of Huangshi. Chemical Speciation \& Bioavailability 28(1-4):209-215. https://doi.org/10.1080/09542299.2016. 1247657

Irene W. Yu. (2000). Bench-scale study of chemically enhanced primary treatment in Brazil (Master's thesis). Retrieved from https://dspace.mit.edu/bitstream/ handle/1721.1/81541/47652255-MIT.pdf?sequence $=2$

Ismail IM, Fawzy AS, Abdel-Monem NM, Mahmoud MH, El-Halwany MA (2012) Combined coagulation-flocculation pretreatment unit for municipal wastewater. Journal of Advanced Research 3(4):331-336. https://doi.org/10. 1016/j.jare.2011.10.004

Kalogo Y, Verstraete W (2000) Technical feasibility of the treatment of domestic wastewater by a CEPS-UASB system. Environmental Technology 21(1):55-65 https://doi.org/10.1080/09593332108618138

Mian HR, Haydar S, Hussain G, E-Hina G (2018) Optimization of sequencing batch reactor for wastewater treatment using chemically enhanced primary treatment as a pre-treatment. Water SA 44(3):399. https://doi.org/10.4314/ wsa.v44i3.07

Neupane DR, Riffat R, Murthy SN, Peric MR, Wilson TE (2008) Influence of source characteristics, chemicals, and flocculation on chemically enhanced primary treatment. Water Environment Research 80(4):331-338. https://doi.org/10. 2175/106143007×221355

Ouali A, Azri C, Medhioub K, Ghrabi A (2009) Descriptive and multivariable analysis of the physicochemical and biological parameters of Sfax wastewater treatment plant. Desalination 246(1-3):496-505. https://doi.org/ 10.1016/j.desal.2008.04.058

Parker D, Esquer M, Hetherington M, Malik A, Robison D, Wahlberg E, Wang J (2000) Assessment and optimization of a chemically enhanced primary treatment system. Proceedings of the Water Environment Federation 2000(8): 560-573. https://doi.org/10.2175/193864700784546594

Svardal K, Kroiss H (2011) Energy requirements for wastewater treatment. Water Science and Technology 64(6):1355-1361. https://doi.org/10.2166/wst.2011. 221

Tik S, Vanrolleghem PA (2016) Chemically enhancing primary clarifiers: modelbased development of a dosing controller and full-scale implementation. Water Science and Technology 75(5):1185-1193. https://doi.org/10.2166/wst. 2016.600

Wang H, Li F, Keller AA, Xu R (2009) Chemically enhanced primary treatment (CEPT) for removal of carbon and nutrients from municipal wastewater treatment plants: a case study of Shanghai. Water Science and Technology 60(7):1803-1809. https://doi.org/10.2166/wst.2009.547

\section{Publisher's Note}

Springer Nature remains neutral with regard to jurisdictional claims in published maps and institutional affiliations.

\section{Submit your manuscript to a SpringerOpen ${ }^{\circ}$ journal and benefit from:}

- Convenient online submission

- Rigorous peer review

- Open access: articles freely available online

- High visibility within the field

- Retaining the copyright to your article

Submit your next manuscript at $\boldsymbol{\nabla}$ springeropen.com 